Jurnal Syntax Imperatif: Jurnal Ilmu Sosial dan

Pendidikan

p-ISSN: 2721-2491 e-ISSN: 2721-2246

Vol. 2, No. 1, Maret 2021

\title{
Pola Didik Orangtua dalam Pembinaan Akhlak Anak (Studi Kasus pada Orangtua Single Parent di Kecamatan Haurgeulis)
}

\author{
Saepulloh \\ Sekola Tinggi Ilmu Agama Islam (STAI) Darul Falah Cihampelas Bandung Barat, \\ Indonesia \\ Saepullohma33@gmail.com
}

\begin{abstract}
Abstrak
Tulisan ini mengkaji pola didik orang tua dalam pembinaan akhlak. Metode yang digunakan dalam penelitian ini adalah kualitatif dan objek penelitian adalah sebagian keluarga di salah satu kabupaten yang ada di Jawa Barat, dimana keluarga yang memenuhi keriteria yaitu keluarga yang "utuh”, dan memiliki anak usia sekolah yang berakhlakul karimah dan disiplin, keluarga single parent dan keluarga "tidak utuh" serta memiliki anak sekolah yang kurang berakhlak baik dan tidak disiplin diri. Data yang terkumpul dianalisis secara reduktif fenomenologis dan editik selama pengumpulan data berlangsung. Kegiatan meliputi mereduksi data, menyajikan data, menarik kesimpulan, dan melaksanakan verifikasi. Dalam mereduksi data pada penelitian ini, penulis melakukan upaya untuk "kembali" kepada yang telah ada terdahulu. Hasil penelitian menunjukan bahwa sebagian besar orang tua cenderung mendidik anak-anak mereka dengan pola otoriter, namun demikian sebagian dari mereka juga menggunakan pola didik demokratis dan bebas. Demikian juga sebagian besar orang tua melakukan pembinaan akhlak kepad anak-anaknya, namun demikian, sebagian dari mereka juga kurang dalam membina akhlak anak-anaknya. Dari hasil analisis penelitian ini dapat disingkapkan sruktur dasar yang membuat anak-anak memiliki dan mengembangkan akhlak yang mulia merupakan kesatuan utuh dari masing-masing pembinaan orang tua. Hubungan pola didik orang tua dalam pembinaan akhlak anak dengan tingkatan apresiasi anak berdasarkan kata hati, nalar dan naluri terjadi karena pasang surutnya kewibawaan dan kepercayaan terhadap orang tua dapat menggetarkan dawai kata hatinya sehingga kewibawaan dan kepercayaan orang tua memiliki medan pesona mental roundrtrip secara psikologis dan emosional, serta nilai-nilai agama harus bermakna secara ekumeni transendentaldalam kerangka hubungan dengan Allah dan sesama manusia.
\end{abstract}

Kata Kunci: Pola didik; Orang Tua; Pembinaan Akhlak;

\section{Pendahuluan}

Keluarga merupakan miniatur dan embrio berbagai unsure system social manusia, suasana keluarga yang kondusif akan menghasilkan warga masyarakat yang baik karena di dalam keluargalah seluruh anggota keluarga belajar berbagai dasar kehidupan bermasyarakat (Sandy Ernawati, 2002, p. 2) Perkembangan peradaban kebudayaan terutama sejak ilmu pengetahuan dan teknologi berkembang telah banyak memberikan pengaruh terhadap tatanan kehidupan manusia. Kehidupan keluarga pun telah banyak mengalami perubahan dan berbeda jauh dari nilai-nilai keluarga yang sesungguhnya sehingga berpengaruh kepada akhlak anak.

Dalam kondisi modernisasi dan globalisasi ini khususnya generasi mudanya dalam kondisi menghawatirkan, dan semua ini berakar dari kondisi kehidupan keluarganya. Oleh karena itu pola didik orang tua dalam pembinaan akhlak anak secara 
dini dalam keluarga merupakan suatu yang sangat urgen dan mendasar. Pola didik orang tua memegang peranan sangat penting dan utama dalam memberikan pembinaan dan bimbingan fisik maupun secara psikologis kepada putra-putrinya dalam rangka menyiapkan genberasi penerus yang lebih baik, berkualitas dan berakhlak mulia.

Dalam kondisi sekarang banyak orang tua yang melalaikan arti penting pendidikan akhlakbagi anak-anaknya. Hal ini dapat kita lihat dari perilaku anak yang menyimpang dari ajaran agama, seperti minum-minuman keras, terlibatnya anak dengan narkoba, tawuran, perilaku sex bebas dan banyak lagi sejenis kenakalan lainnya. Dari kenyataan ini sesuai dengan yang digambarkan oleh (Abdul Hafidz, 1997, p. 159) yang menyatakan bahwa sebagian orang tua melalaikan kepentingan pembinaan budi pekerti dan sopan santun anak, bahkan mereka menganggap hal tersebut sebagai hal biasa yang dapat diabaikan begitu saja.

Berdasarkan pernyataan di atas, bahwa pendidikan akhlak sangat penting dan urgen sekali dan ditunjang dengan pola didik orang tua bias dijadikan sebagai alternative dalam mendidik anak.

Adapun rumusan masalah dalam penelitian ini adalah "Bagaimanakah pola didik orang tua dalam pembinaan akhlak anak?"

\section{A. Pola Didik Orang Tua \\ Definisi Pola Didik Orang Tua}

Dalam keluarga atau rumah tangga, istilah pola didik dalam kamus umum bahasa Indonesia mengandung makna memelihara dan member latihan, ajaran, pimpinan mengenai akhlak dan kecerdasan pikiran, atau cara mendidik (Poerwadarminta, 1984, p. 250). Sedangkan menurut (Hasyim Umar, 1980, p. 12) pola didik adalah perlakuan orang tua dalam rangka memenuhi kebutuhan, member perlindungan, dan mendidik anak dalam kehidupan sehari-hari.

Dengan demikian bila istilah pola didik ini dihubungkan dengan kepemimpinan orang tua dalam membina akhlak anak ialah system kerja orang tua dalam membimbing dan menuntun anak-anaknya dalam berperilaku, bertindak dan berbicara menurut akhlak yang mulia dalam ajaran Islam (Shochib, 2001, p. 15)

Pengertian pola didik orang tua menurut (Zahara Idris, 1981, p. 87) pembentukan watak anak. Sedangkan menurut (Thoha, 1996, p. 110)secara tegas membagi pola didik orang tua yaitu demokratis, otoriter, dan bebas (lazier fair). Pola didik demokratis mngacu kepada penekanan aspek musyawarah seperti:

a. Dalam keluarga dengan cara musyawarah

b. Menentukan peraturan dan disiplin dengan mempertimbangkan keadaan dan perasaan anak

c. Terdapatnya hubungan yang harmonis dalam keluarga

d. Anak ikut dalam memberikan pendapat

e. Semua larangan dan perintah yang disampaikan kepada anak selalu bersifat mendidik. 
Pola didik otoriter mempuntai cirri-ciri sebagai berikut :

a. Anak sepenuhnya harus memenuhi peraturan yang dibuat orang tuanya

b. Orang tua menghukum anak apabila berbuat kesalahan

c. Jika terjadi perbedaan pendapat, maka anak dianggap melawan orang tua

d. Orang tua lebih cenderung memberikan perintah dan larangan kepada anak

e. Orang tua mempunyai hak penuh atas segala sesuatu.

Pola didil lazier fair mempunyai cirri-ciri sebagai berikut :

a. Membiarkan anak bertindak sendiri, dan orang tua kurang memonitor dan membimbing anak

b. Mendidik anak acuh tak acuh

c. Memberikan kebutuhan yang material adalah hal yang utama

d. Membiarkan apa saja yang dilakukan anak

e. Kurangnya keakrabanorang tua dan anak.

\section{B. Pentingnya pola Didik Orang Tua bagi Anak pada Era Global}

Dalam era global dewasa ini, kompleksitas masalah kehidupan mengalami perubahan yang sangat cepat sekali, hal ini memberikan kesan bahwa kehidupan seharihari semakin menggalau dan beraneka. Dengan cara pandang yang cermat, tajam dan menyeluruh. Mengapa perubahan itu terjadi? Pertanyaan ini membuat fenomenafenomena menunjukan keteraturannya, perubahan yang cepat mengharuskan adanya berbagai upaya terhadap anak agar memiliki kemampuan untuk mengantisipasi, mengakomodasi dan mewarnainya. Karena anomaly era global secara maknawi semakin meningkat digandrungi oleh anak-anak misalnya, situs porno, seks bebas, ekstasi, minuman keras, tawuran dan sejenisnya. Dengan demikian perlu adanya posisi dan tanggung jawab dari orang tua, karena orang tua berkewajiban meletakkan dasar-dasar moral kepada anak-anaknya bersama sekolah dan masyarakat.

Akhlak merupakan subtansi esensial di era global untuk dimiliki dan dikembangkan dalam bentuk perilaku anak-anak, sehingga mereka memiliki control internal untuk berperilaku yang senantiasa taat moral sehingga anak-anak tidak hanyut oleh arus globalisasi, tetapi sebaliknya ia mampu mewarnai dan mengakomodasi (Shochib, 2001, p. 12) Bantuan orang tua dalam meletakkan dasar-dasardan pengembangan perilaku berbakti anak adalah dengan menciptakan situasi dan kondisi yang mendorong anak memiliki dasar-dasar disiplin diridalk keluarga dan pengembangannya meliputi :

a. Orang tua sebagai pendidik

b. Anak sebagai si terdidik.

Pengakuan subjek si terdidik dan pendidik mengisyaratkan adanya identitas diri yang diakui eksistensinya. Penampilan anak didik yang kongkret dalam situasi pendidikan mencakup tema: Pertama Badannya, meliputi penampialan, kehadiran, dan gerak-geriknya teramati mendapatkan maknanya dalam kehidupan keluarga yang 
bersangkutan. Kedua dunianya, seperti bagaimana alam pikiran dan pandangannya, kebiasaan dan selera dan hal-hal yang melatarbelakangi penghayatan dan pemaknaan terhadap kehidupan, orang sekitar. Ketiga historis, pengalaman pada masa lalu, terhadap angan-angan dan cita-citanya serta harap di masa dating. Kelima komunikasi, bagaimana komunikasinya dengan Allah melalui pengamalan beribadahnya, dengan orang tua, dengan guru, dengan masyarakat dalam lingkunan sehari-hari.

\section{Pola Didik Orang Tua dalam membantu Anak Memiliki Akhlak Mulia}

Pola didik orang tua dalam membantu anak memiliki akhlak mulia ini adalah upaya orang tua yang diaktualisasikan terhadap penataan; lingkunagan fisik, lingkungan sosial, pendidikan internal dan eksternal, dialog dengan anak-anaknya, suasana psikologis, sosiobudaya, perilaku orang tua saat terjadinya pertemuan dengan anakanak, control terhadap perilaku anak-anak dan menentukan nilai-nilai ajaran agama serta moral sebagai dasar berperilaku yang diupayakan kepada anak-anak. Pola didik lain yang dikembangkan antara lain meliputi:
a. Anak berdisiplin diri
b. Keterkaitan pola didik orang tua dengan akhlak anak
c. Dinamika anak memiliki akhlak dan disiplin diri
d. Kewajiban orang tua dalam mendidik akhlak anak
e. Macam-macam pola didik yang direrapkan dalam keluarga.

\section{Pembinaan Akhlak Anak \\ Pengertian Akhlak dan Objek Kajiannya}

Perkataan akhlak berasal dari bahasa Arab jama' dari "khulukun” yang berarti budi pekerti, peragai, tingkah laku atau tabiat (Ya'qub, 1983, p. 11) Kalimat tersebut mengandung arti persesuaian dengan perkataan "khuluqun" yang berarti kejadian, serta erat hubungannya dengan "khaliq" yang berarti yang diciptakan. Akhlak adalah sifat yang tertanam dalam jiwa yang menimbulkan macam-macam perbuatan.

Objek kajiannya adalah perbuatan manusia, dan norma atau aturan yang dijadikan untuk mengukur perbuatandari segi baik dan buruk. Akhlak dalam islam memiliki fungsi utama dan pembentukan akhlak dilakukan secara integral melalui rukun iman dan rukun Islam dengan tujuan unity of God dan social equity.

\section{Proses Pembentukan Akhlak Anak}

Akhlak anak merupakan produk disiplin (Shochib, 2001, p. 21) Kepemilikan perilaku pembentukan akhlak anak melalui proses belajar. Pada awal proses belajar perlu ada orang tua. Hal ini dapat dilakukan dengan cara melatih, membiasakan diri berperilaku sesuai dengan nilai-nilai agama dan berdasarkan acuan moral serta perlu adanya kontrol orang tua untuk pengembangannya (Shochib, 2001, p. 22)

Kontrol orang tua meliputi kontrol internal dan eksternal serta kontrol diri. Kontrol diri memiliki subtansi asesmen diri, perekaman diri determinasi diri terhadap penguatan. 


\section{Dasar-dasar Pembinaan akhlak}

Pembinaan akhlak kepada anak merupakan wadah yang sangat penting dalam membentuk kepribadian yang beriman dan bertakwa kepada Allah (Ya'qub, 1983, p. 11) Faktor-foktor yang mempengaruhi dalam pembentukan akhlak meliputi, pembawaan sejak lahir, bakat, faktor lingkungan, faktor internal. Sedangkan dasar-dasar pembinaan akhlak adalah dari Al-Qur'an dan Hadits.

\section{Metodologi Penelitian}

Metode yang digunakan dalam penelitian ini adalah menggunakan pendekatan kualitatif dengan memfokuskan pada data-data kualitatif. Data tersebut diperoleh melalui proses kajian yang mendalam terhadap realitas sosial keagamaan masyarakat. Data yang terkumpul dalam penelitian ini dianalisis secara reduktif fenomenologis dan editik selama pengumpulan data berlangsung.

\section{Hasil dan Pembahasan}

\section{Pola didik orang tua yang kurang mampu dalam pembinaan akhlak dan tidak disiplin diri}

Pemilihan data dilakukan untuk ketajaman analisis demi kepentingan teoritis dan pedoman praktek. Pola didik orang tua yang kurang dapat membantu anak memiliki dan mengembangkan disiplin diri dan akhlak anak sebagai berikut:

\section{Penataan Lingkungan Fisik}

Penataan lingkungan fisik yang dilakukan oleh tuan dan Nyonya $M$ telah menyikapi adanya upaya mereka dalam pembinaan akhlak, sosial, ekonomi, dan kebersihan. Persoalannya, apakah pola didik mereka telah memberikan motivasi kepada anak untuk belajar memiliki? Motivasi itu bagi anak lakil-laki mereka terutama $\mathrm{H}$ (anak pertama Tn. M) tidak dihayati sebagai bahan dialog karena anak itu sering sekali menampilkan perilaku atau akhlak yang tidak terpuji atau perilaku melanggar. $\mathrm{H}$ sering keluyuran pada malam hari dan terpengaruh oleh teman-temannya untuk melakukan perilaku yang menyimpang serti mabuk-mabukan, berkata kasar kepada orang tua dan lalai dalam menjalankan perintah agama seperti shalat. Ini menunjukan bahwa penataanfisik rumah tidak dirasakan oleh mereka. Mereka pulang hanya untuk makan, meminta uang, dan hanya sebagai tempat berteduh.

Sedangkan penataan lingkunagan fisik yang dilakukan oleh Tuan dan Nyonya A telah menyikap adanya upaya mereka dalam pembinaan akhlak anaknya, tetapi karena kesibukan mereka sebagai pedagang yang waktunya sehari-hari dihabiskan untuk melayani pembeli sehingga anak-anak mereka kurang mendapat perhatian. Seperti yang di alami oleh I, T dan M, mereka merasakan menganggap bahwa pulang ke rumah berarti akan memperoleh omelan-omelan dari orang tuanya karena tidak mau membantu berjualan di took. Rumah tidak lagi memberikan perlindungan dan rasa aman. Dalam penataannya belum mencerminkan adanya nuansa nilai-nilai moral. 
Berbeda dengan anak perempuan mereka yaitu $\mathrm{T}$, anak ini merasakan upaya orang tua sebagai ajakan baginya untuk memiliki nilai moral kewanitaan. Kemampuan Nyonya A untuk menyadarkan kebutuhan anak perempuannya sebagai wanita disebabkan oleh kedekatan dan keakraban yang memuat dialog-dialog intensif. Oleh karena itu rumah dirasakan sebagai suatu wadah untuk memiliki keterampilan dan pengetahuan nilai moral dalamm kodratnya sebagai wanita.

\section{Penataan Lingkungan sosial}

Penataan lingkungan social internal keluarga $\mathrm{M}$ belum menunjukan upaya membantu anak untuk berdekatan dan keakraban dengan nilai moral, social, dan ekonomi, begitu pula yang dialami oleh keluarga A

\section{Penataan Lingkungan Pendidikan}

Penataan lingkungan pendidikan keluarga $\mathrm{M}$ menyikap upaya pembinaan akhlak. Anak yang merasakan motivasi untuk dihayati dan mengapresiasi adalah anak perempuanya dan adiknya ( $\mathrm{N}$ dan $\mathrm{A}$ ), sedangkan anak laki-lakinya $(\mathrm{H})$ tidak merasakan. Karena nyonya $\mathrm{M}$ sebagai seorang istri kurang mampuberperilaku konsisten, sejak pulang dari bekerja menjadi TKW di Timur Tengah. Nyonya M sering menunjukan perilaku yang kurang baik. Hal ini dirasakan sebagai suatu ketidak wibawaan dan tidak percayaan yang diakui anak dalam nilai moral.

\section{Kontrol Orang Tua dalam Pembinaan Akhlak}

Interpretasi dalam daftar control Tn dan Ny. M dalam pembinaan akhlak anaknya bertujuan untuk menyingkap makna control orang tua dalam perilaku anak-anaknya. Kontrol Tn dan Ny. M kepada anak-anaknya (H, N dan At) tidak dipahami dan tidak dimengerti sebagai control, tetapi sebagai pertentangan dirinya dengan orang tua. Hal ini dirasakan oleh $\mathrm{H}$ sebagai anak lali-laki tertua. Pertentangan tersebut menunjukan bahwa kewibawaan dan kepercayaan kepada orang tua dirasakan olehnya telah padam.

\section{Pola didik orang tua yang mampu dalam pembinaan akhlak dan disiplin diri}

Pemilihan data dilakukan untuk ketajaman analisis demi kepentingan teoritis dan pedoman praktek. Pola didik orang tua dipengaruhi oleh faktor:

\section{Penataan lingkungan fisik}

Interprestasi terhadap data penataan lingkungan fisik keluarga $\mathrm{E}$ bertujuan untuk menyingkap nilai-nilai akhlak yang diapresiasi anak terhadap bantuan yang diberikan orang tua kepada anaknya agar memiliki akhlak yang mulia, sedangkan pada keluarga Tn. E telah membuktikan adanya upaya agar anak-anak memiliki akhlak yang mulia, anak yang taat pada agama dan kepada orang tuanya.

Kondisi di dalam rumah mencerminkan relasi nilai-nilai agama sehingga menumbuhkan motivasi untuk belajar dari perilaku Tn dan Ny. M serta anak-anaknya (Az, E, N, dan A), dan begitu pula pada keluarga A serta anak-anaknya (I, N, E, D Ne 
dan M). Fakta ini menunjukan bahwa pengaturan ruangan fisik dalam keluarga dapat digunakan untuk mengupayakan nilai-nilai agama dalam bentuk pola didik demokrasi. Penghayatan anak-anak terhadap hasil tersebut dapat dibaca dari akhlak mereka seperti dalam menjalankan shalat, tingkah lakunya dan penciptaan nuansa yang tentram dalam keluarga.

\section{Penataan Lingkungan social}

Interprestasi terhadap penataan lingkungan social internal dan eksternal bertujuan menyingkap nilai-nilai yang diapresiasi anak dalam menerima pola didik orang tua dalam pembinaan akhlak.

Penataan lingkungan social internal keluarga Tn dan Ny E telah dirasakan sebagai motivasi oleh anak-anaknya. Mereka merasakannya sebagai bantuan karena adanya suasana kedekatan dan keakraban di antara orang tua dengan anak sehingga mereka mampu berkomunikasi secara efektif. Begitu juga keluarga Tn dan Ny U dengan anakanaknya juga keluarga Ny Ac.

Penghayatan anak-anak terhadap hal tersebut merupakan bimbingan, arahan, dan bantuan untuk semakin mendekatkan dan mengakrabkan mereka dengan nilai-nilai yang tampak dari realitas akhlah anak-anaknya keseharian. Mereka belajar kurang dari 2 jam, mereka serius dalam belajar tanpa adanya paksaan.

\section{Penataan Lingkungan Pendidikan}

Interprestasi terhadap penataan lingkungan pendidikan internal dan eksternal bertujuan untuk menyingkap nilai-nilai yang diapresiasi anak dalam menerima bantuan orang tua untuk memiliki dasar-dasar akhlak yang mulia. Tindakan Tn. dan Ny. E dalam menata lingkungan pendidikan internal telah menyingkapkan adanya upaya terhadap anak- anaknya (ag dan Ev) agar memiliki nilai-nilai akhlak mulia, social, ekonomi, disiplin diri dan demokrasi dan sebagai pendidik mampu terjun ke dunia anak. Sedangkan tindakan ibu Ac dalam menata lingkungan pendidikan internal telah menyingkapkan adanya upaya terhadap anak-anaknya begitu juga Tn. Dan Ny. Mu.

\section{Kontrol Orang Tua dalam Pembinaan akhlak}

Ditemukan fakta-fakta bahwa akhlak Tn. Dan Ny. E selama berlangsungnya pertemuan dengan anak-anaknya telah mencerminkan adanya nilai-nilai dasar agama. Bahkan setiap pertemuan yang mereka lakukan dengan anak-anaknya senantiasa didasari oleh tampilnya nilai-nilai akhlak mulia. Sedangkan dalam keluarga ibu Ac meskipun hidup seorang diri dalam mengasuh dan mendidik anak-anaknya mencerminkan adanya nilai-nilai dasar agama, bahkan setiap pertemuan yang mereka lakukan dengan anak-anaknya senantiasa didasari oleh tampilnya niali-nilai mulia.

\section{Pembinaan Akhlak Anak}

Untuk mengetahui pembinaan akhlak anak ruang lingkupnya sangat luas sekali, makanya penulis membatasi yaitu akhlak kepada allah dan kepada orang tua. Akhlak 
kepada Allah berupa menjalankan semua perintah-Nya dan menjauhi larangan-Nya, sedangkan akhlak kepada orang tua berupa mematuhi perintah orang tua, menghormati kedua orang tua, berkata lemah lembut kepada orang tua, dan mendoakan kepada orang tua.

Dari temuan menunjukan bahwa lingkungan internal dan eksternal dalam keluarga Tn. Dan Ny. M dapat dibaca dari hasil pengamatan yang tajam bahwa rumah keluarga Tn dan Ny. M dikelilingi oleh berbagai lingkungan pendidikan, yaitu Madrasah Aliyah, Sekolah Mengah Kejuruan dan Masjid.

Dengan lingkungan yang strategis seprti itu semestinya bias dimanfaatkan oleh orang tua sebagai sarana pendidikan dan menekankan agar anak-anaknya belajar agama di Madrasah Diniyah yang ada di masjid.

\section{Pola didik Orang Tua Dalam Pembinaan Akhlak di kecamatan Haurgeulis}

Untuk mengetahui pola didik orang tua dalam pembinaan akhlak peneliti melakukan pengamatan yang sangat tajam ditambah dengan wawancara yang mendalam serta dikaitkan dengan fenomena dan realitas kehidupan keluarga dalam mendidik dan membina akhlak anak. Temuan menunjukan bahwa:
a. Tindakan mengerjakan perintah agama
b. Tindakan yang dilakukan bila anak berselisih paham
c. Berlaku lemah lembut kepada anak
d. Sikap orang tua kepada anak yang berkata kasar dan berbohong
e. Pengajaran sopan santun kepada anak
f. Memaksa anak untuk mematuhi peraturan dan disiplin diri
g. Memberikan teladan kepada anak
h. Berkata kasar kepda anak

\section{Akhlak Anak Kepada Orang Tuanya di Kecamatan Haurgeulis}

Akhlak anak kepada orang btuanya meliputi:
a. Menjalankan perintah agama dan mematuhi orang tua
b. Menghormati orang tua
c. Sikap bila orang tua membutuhkan pertolongan
d. Berlaku lemah lembut kepada orang tua
e. Berkata kasar kepada orang tua
f. Berbohong kepada orang tua
g. Mendoakan orang tua 


\section{Kesimpulan}

Berdasarkan hasil penelitian dan analisis data serta pembahasan yang telah dilakukan, maka penulis dapat mengambil kesimpulan sebagai berikut ini. Sebagian besar orang tua cenderung mendidik anak-anak mereka dengan pola otoriter, memaksakan kehendak kepada anak-anaknya. Hanya sebagian kecil saja orang tua yang cenderung melaksanakan pola didik yang demokratis termasuk yang menerapkan pola didik lazier fair. Sebagian besar orang tua cenderung kurang dalam pembinaan akhlak kepada anak-anaknya. Hal ini terbukti dari sikap mereka yang cenderung tidak menegur anak-anaknya yang tidak mengerjakan shalat dan mengaji, serta kurang dalam memberikan teladan yang baik terutama dalam mengerjakan perintah agama.

Pola didik orang tua dalam pembinaan akhlak anak berpengaruh positif dan signifikan dalam membentuk anak menjadi anak yang berakhlak mulia. Bentuk ketaatannya itu bias dilihat dalam aktualisasi kehidupannya sehari-hari.

Kewibawaan dan kepercayaan orang tua memiliki mental roundtrif secara psikologis dan emosional. Jika anak memiliki mental roundtrif secara psikologis dan emosional maka mitivasi yang dipercayakan oleh orang tua dirasakan berasal dari dalam dirinya 
Saepulloh

\section{BIBLIOGRAFI}

Abdul Hafidz. (1997). Mendidik Anak Bersama Rasulullah. Bandung: Albayan.

Hasyim Umar. (1980). Anak Shaleh. Surabaya: Bina Ilmu.

Moleong, L. J. (2007). Metode penelitian kualitatif. Bandung: Remaja Rosdakarya.

Poerwadarminta, W. J. S. (1984). Kamus Umum Bahasa Indonesia, Jakarta: PN. Balai Pustaka.

Sandy Ernawati. (2002). Pola Asuh Orang Tua Tehadap Penerimaan Diri Remaja Putri Masa Pubertas. UIN Bandung.

Shochib, M. (2001). Pola Asuh Orang Tua Untuk Mengembangkan Disiplin Diri. Jakarta: PT Rineka Cipta.

Thoha, H. M. C. (1996). Kapita selekta pendidikan Islam. Pustaka Pelajar.

Ya'qub, H. H. (1983). Etika Islam: pembinaan akhlaqulkarimah suatu pengantar. CJ. Diponegoro, Bandung.

Zahara Idris. (1981). Dasar-dasar Kependidikan. Padang: Aksara Raya. 